Article

\title{
ZnO Quantum Dots Modified by pH-Activated Charge-Reversal Polymer for Tumor Targeted Drug Delivery
}

\author{
Yifan Wang ${ }^{1}$, Liang $\mathrm{He}^{1}$, Bing Yu ${ }^{1,2}$, Yang Chen ${ }^{1}$, Youqing Shen ${ }^{1,3}$ and Hailin Cong $1,2, * \mathbb{C}$ \\ 1 Institute of Biomedical Materials and Engineering, College of Materials Science and Engineering, \\ College of Chemistry and Chemical Engineering, Qingdao University, Qingdao 266071, China; \\ wangyifan@qdu.edu.cn (Y.W.); lianghe169@163.com (L.H.); yubingqdu@yahoo.com (B.Y.); \\ cyalex1995@163.com (Y.C.); amnano@163.com (Y.S.) \\ 2 Laboratory for New Fiber Materials and Modern Textile, Growing Base for State Key Laboratory, \\ Qingdao University, Qingdao 266071, China \\ 3 Key Laboratory of Biomass Chemical Engineering of Ministry of Education, Center for Bionanoengineering, \\ and Department of Chemical and Biological Engineering, Zhejiang University, Hangzhou 310027, China \\ * Correspondence: hailincong@yahoo.com; Tel.: +86-532-8595-3995; Fax: +86-532-8595-5529
}

Received: 25 October 2018; Accepted: 12 November 2018; Published: 15 November 2018

\begin{abstract}
In this paper, we reported a $\mathrm{pH}$ responsive nano drug delivery system (NDDS) based on $\mathrm{ZnO}$ quantum dots (QDs) for controlled release of drugs. Zwitterionic poly(carboxybetaine methacrylate) (PCBMA) and poly(2-(dimethylamino) ethyl methacrylate) (PDMAEMA) were introduced to modify $\mathrm{ZnO}$ QDs, which can help enhance water stability, increase blood circulation time, and promote endocytosis. After tuning of PCBMA/PDMAEMA ratios, the ZnO@P(CBMA-co-DMAEMA) nanoplatform shows a sensitive switch from strong protein adsorption resistance (with negatively charged surface) at physiological $\mathrm{pH}$ to strong adhesion to tumor cell membranes (with positively charged surface) at the slightly acidic extracellular $\mathrm{pH}$ of tumors. Anti-cancer drug, Doxorubicin (DOX), molecules were demonstrated to be successfully loaded to ZnO@P(CBMA-co-DMAEMA) with a relatively large drug loading content (24.6\%). In addition, ZnO@P(CBMA-co-DMAEMA) loaded with DOX can achieve lysosomal acid degradation and release of DOX after endocytosis by tumor cells, resulting in synergistic treatment of cancer, which is attributed to a combination of the anticancer effect of $\mathrm{Zn}^{2+}$ and DOX.
\end{abstract}

Keywords: Zinc oxide quantum dots (ZnO QDs); poly(carboxybetaine methacry late) (PCBMA); poly(2-(dimethylamino) ethyl methacrylate) (PDMAEMA); drug delivery

\section{Introduction}

Cancer is a serious threat to people's health all over the world. Nowadays, cancer therapy relies mainly on chemotherapy and radiation therapy, which has great side effects along with great sequela [1,2]. Nano drug delivery systems (NDDSs) are commonly researched as a strategy for tumor treatments, which can help avoid damaging healthy cells, and improve cancer treatment routes $[3,4]$. Based on the enhanced permeability and retention (EPR) effect, NDDSs can reach to lesions, which are modified by one or two major types of protein resistant materials [5], polyethylene glycol (PEG) polymers [6,7] or zwitterionic polymers [8-10]. Unfortunately, the PEGylation of NDDS has a negative effect on the internalization of NDDS due to the strong protein adsorption resistance structure of PEG, thus reducing the therapeutic effect [11-13].

$\mathrm{ZnO}$ quantum dots (QDs) have drawn much attention because of the advantages of low cost, ease of availability, biocompatibility, and high thermal stability $[14,15]$. The unprotected ZnO QDs can be 
employed as nanocarriers for drug delivery as they can decompose completely to zinc ions at $\mathrm{pH}=5$ in aqueous solution $[16,17]$. In addition, zinc ions are toxic to tumor cells, which can help achieve synergistic cancer treatment with the delivered drugs [18]. However, there are several drawbacks of ZnO QDs, including poor water stability and easy agglomeration, which hinders its application in the biological domain [19-21]. In recent years, the use of functional modifications of ZnO NPs in the field of drug delivery systems has drawn much attention. According to previous reports, stable ZnO NPs can be modified with a polymer of methyl methacrylate (MMA) [22], polystyrene (PS) [23], oleic acid [24], folic acid [25], hyaluronic acid [26], and poly(2-(dimethylamino) ethyl methacrylate) (PDMAEMA) [27], etc. The zwitterionic polymers have been developed to enhance retention and internalization due to the difference of a mildly acidic extracellular $\mathrm{pH}$ in tumor tissues $(\mathrm{pH}=6.5-6.9)[28,29]$ as compared to healthy tissue under physiological conditions ( $\mathrm{pH}=7.2-7.4)[30,31]$. Poly(carboxybetaine methacrylate) (PCBMA), a zwitterionic polymer, has a similar structure to glycine betaine, which is a kind of solute used to osmotically regulate living organisms. It is attractive for many biomedical applications based on its biomimetic and non-toxic nature [32,33]. Furthermore, PCBMA-decorated surfaces help prevent non-specific protein adsorption, which have a positive influence on the internalization of the NDDS [34-37].

In this study, we invented a $\mathrm{pH}$ responsive NDDS based on the ZnO QDs coated with zwitterionic polymer P(CBMA-co-DMAEMA) (Scheme 1a), which can help enhance water stability, increase blood circulation time, and promote endocytosis. Doxorubicin (DOX) was selected as a model drug for this study and was loaded to the NDDS by covalent interactions and formation of a $\mathrm{Zn}^{2+}$-DOX chelate complex. After ZnO@P(CBMA-co-DMAEMA) entering the cancer cells, lysosomal acid degradation can be achieved and the anticancer drug, DOX, is released, resulting in zinc ion synergistic treatment of cancer (Scheme 1b).

$\mathbf{a}$
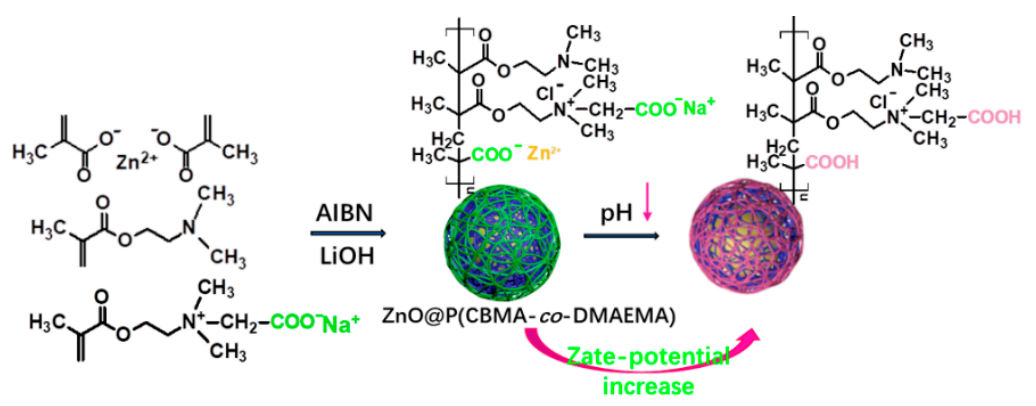

b

\begin{tabular}{l|ll} 
Blood environment & Tumor extracellular $\quad \mathrm{pH}$ Responsive delivery
\end{tabular}

ZnO@P(CBMA-co-DMAEMA)

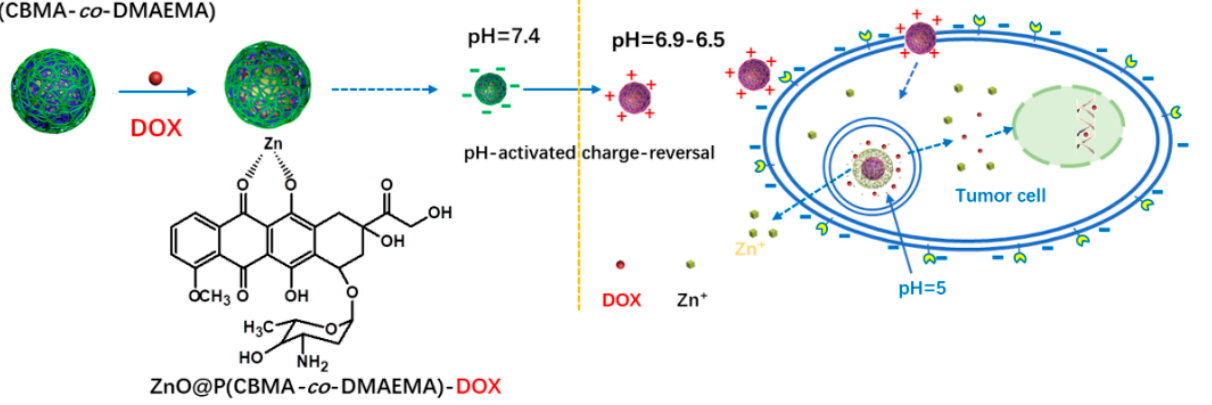

Scheme 1. (a) Procedures to synthesize ZnO@P(CBMA-co-DMAEMA) NDDS; (b) schematic illustration of the ZnO@P(CBMA-co-DMAEMA) NDDS for drug delivery and deeply penetrating cancer therapy motivated by affinity switching.

\section{Materials and Methods}

\subsection{Materials}

Zinc chloride, triethylene glycol (TEG), ethanol, and lithium hydroxide $\left(\mathrm{LiOH} \cdot \mathrm{H}_{2} \mathrm{O}\right)$ were purchased from Qingdao Renhe Xing Experimental Technology Co., Ltd. (Qingdao, China) and used 
without further purification. Methacrylic acid (MAA) was obtained from Aladdin (Shanghai, China) and distilled under reduced pressure prior to use. 2, 2-azobisisobutyronitrile (AIBN) was purchased from Qingdao Zhengye Experimental Technology Co., Ltd. (Qingdao, China) and recrystallized from ethanol. 2-(dimethylamino)ethyl methacrylate (DMAEMA, 97\%). Doxorubicin (in the form of a hydrochloride salt) was obtained from Aladdin.

\subsection{Synthesis of Zinc Dimethacrylate}

Zinc dimethacrylate $\left(\mathrm{Zn}(\mathrm{MAA})_{2}\right)$ was synthesized based on the reported method [38]. $3.2 \mathrm{~g}$ sodium hydroxide was dissolved in $20 \mathrm{~mL}$ deionized water, followed by $7.88 \mathrm{~g}$ methacrylic acid being added to the solvent. Then, it was sufficiently stirred to make sure reacting was completed. PH was tuned to 7.0 before adding $\mathrm{ZnCl}_{2}$ solution. Then, vacuum filtration was used to get the solid precipitate followed by washing for several times. Finally, the product was obtained after lyophilization.

\subsection{Preparation of ZnO@P(CBMA-co-DMAEMA) Hybrid Nanoparticles with Different CBMA/DMAEMA Ratios}

ZnO@P(CBMA-co-DMAEMA) was prepared by the sol-gel method [39]. First, $100 \mathrm{mg} \mathrm{Zn}(\mathrm{MAA})_{2}$ was dissolved in $20 \mathrm{~mL}$ TEG under magnetic stirring at $72{ }^{\circ} \mathrm{C}$ for $3 \mathrm{~h}$. Then, the solution was cooled down to room temperature. Different amounts of CBMA, DMAEMA, and 5mg AIBN were added. The solution was stirred and heated at $72{ }^{\circ} \mathrm{C}$ for $10 \mathrm{~min}$. Afterwards, $10 \mathrm{mg} \mathrm{LiOH} \cdot \mathrm{H}_{2} \mathrm{O}$ and another $5 \mathrm{mg}$ AIBN were added into the reaction. Then, the reaction solution was kept stirring at $72{ }^{\circ} \mathrm{C}$ for $2 \mathrm{~h}$. Finally, the solution was cooled down to room temperature and dialyzed against deionized water for 3 days.

\subsection{Stability Tests of the $\mathrm{ZnO}$-Based NDDSs}

The resistance protein adsorption capability of ZnO NDDSs $\left(1 \mathrm{mg} \mathrm{mL}^{-1}\right)$ coated with different polymers (each condition has 5 samples) in 10\% FBS solution were investigated with turbidimetry. The turbidity of samples was investigated at $600 \mathrm{~nm}$ by UV absorption spectrum at different time $(0,1$, $2,3,4,5,6,8,10,15$ days).

\subsection{Characterization}

Fourier transform infrared (FT-IR) analysis was carried out using $\mathrm{KBr}$ discs in the region of $4000-500 \mathrm{~cm}^{-1}$ by a Fourier transform infrared spectrophotometer (Shimadzu IR prestige-21, Osaka, Japan). Ultraviolet-visible (UV-Vis) absorption spectra were performed on a Lambda 750 spectrophotometer (PerkinElmer, New York, NY, USA). The photoluminescence (PL) spectra were recorded on a Shimadzu RF-5301 PC spectrofluorophotometer (Osaka, Japan). The particle sizes of NPs were obtained by a Britain Malvern PSA (NANO2590, Beijing, China) submicron particle size analyzer with angle detection at $90^{\circ}$. The microstructure and morphology of the NPs were examined by high-resolution transmission electron microscopy (HRTEM, Germany, Berlin) on a Philips Tecnai G2F20 microscope (Philips, Amsterdam, Netherlands) with an accelerating voltage of $200 \mathrm{kV}$. The crystal structure of the NPs was investigated by XRD (Rigaku D/MAX-2400 X-ray diffractometer with $\mathrm{Ni}$-filtered $\mathrm{Cu} \mathrm{K} \alpha$ radiation $(\lambda=1.54056)$, Osaka, Japan).

\subsection{Drug Loading and Release}

$0.5 \mathrm{mg} \mathrm{mL}^{-1}$ DOX solution $(4 \mathrm{~mL})$ was mixed with the solution of the ZnO-based $(10 \mathrm{mg})$ NDDSs, followed by keeping it in the dark for $12 \mathrm{~h}$. The drug loading content was calculated by UV-vis absorbance of DOX at $490 \mathrm{~nm}$. The calibration curve obtained by a series of DOX solutions with different concentrations under the same conditions was used to be the reference system. In vitro release experiments were carried out at different $\mathrm{pH}$ values (PBS buffer). Firstly, $1 \mathrm{~mL}$ ZnO@PDMAEMA-DOX or $\mathrm{ZnO} @ \mathrm{PC}_{400} \mathrm{D}_{400}$-DOX was put in a dialysis bag (1000 Da). Then, the dialysis bag was immersed in $200 \mathrm{~mL}$ PBS buffer or acetate buffer, followed by stirring for $24 \mathrm{~h} .1 \mathrm{~mL}$ 
sample was collected periodically. Meanwhile, each sample was replaced with the same volume of fresh buffer. UV absorption spectrum was used to measure the amount of released DOX of the samples.

\subsection{Confocal Microscopy}

Live cells were imaged by a laser scanning confocal microscope (Zeiss LSM 800, Germany, Berlin). Firstly, HepG2 cells were seeded onto the glass-bottomed culture dishes ( $35 \mathrm{~mm}$, MetTek, Beijing, China) with a density of $5 \times 10^{4}$ cells / dish, followed by incubating at $37^{\circ} \mathrm{C}$ in $5 \% \mathrm{CO}_{2}$ overnight. Then, the cells were mixed with $\mathrm{ZnO} @ \mathrm{PC}_{400} \mathrm{D}_{400}\left(20 \mu \mathrm{g} \mathrm{mL}{ }^{-1}\right)$ or $\mathrm{ZnO@PC} \mathrm{P}_{400} \mathrm{D}_{400}$-DOX $\left(\mathrm{DOX} 0.5 \mu \mathrm{g} \mathrm{mL}{ }^{-1}\right)$. After $4 \mathrm{~h}$ incubation, PBS was used to wash the cells 3 times to remove the $\mathrm{ZnO} @ \mathrm{PC}_{400} \mathrm{D}_{400}$ or $\mathrm{ZnO@PC}{ }_{400} \mathrm{D}_{400}$-DOX complexes, which was adsorbed on the surface of the cell membrane. Finally, the laser scanning confocal microscope was used to image the cells under an excitation wavelength of $360 \mathrm{~nm}$.

\subsection{Cytotoxicity Analysis}

The cytotoxicity of the NPs were assessed through MTT experiment. Firstly, the HepG2 cells were seeded in a 96-well plate at $2 \times 10^{4}$ cells/well and incubated overnight. ZnO QDs and the corresponding increasing concentrations of $\mathrm{Zn}^{2+}$ ions $\left(\mathrm{ZnCl}_{2}\right)$ from 2.5 to $40 \mu \mathrm{g} \mathrm{mL}{ }^{-1}$ were incubated with HepG2 cells for $24 \mathrm{~h}$. Similarly, free DOX and various concentrations (2.5 to $40 \mu \mathrm{g} \mathrm{mL}^{-1}$ ) of $\mathrm{ZnO@PC} \mathrm{P}_{400} \mathrm{D}_{400}$ and $\mathrm{ZnO} @ \mathrm{PC}_{400} \mathrm{D}_{400}$-DOX were also incubated with HepG2 cells for $24 \mathrm{~h}$. Afterwards, the medium was replaced with $100 \mu \mathrm{L}$ MTT (5 mg in $1 \mathrm{~mL}$ PBS and $9 \mathrm{~mL}$ FBS) and incubated for another $4 \mathrm{~h}$. Finally, all medium was removed and $100 \mu \mathrm{L}$ DMSO was added and shaken for $15 \mathrm{~min}$. The absorbance of MTT at $490 \mathrm{~nm}$ was measured by an enzyme-labeled instrument. The cell viability $(\%)$ was calculated as:

$$
\text { cell viability }(\%)=\left(A_{S} / A_{C}\right) \times 100 \%
$$

where $A_{s}$ is the absorbance of the sample well and $A_{c}$ is the absorbance of the control well. The data was calculated as the mean of 5 samples of each condition.

\section{Results and Discussion}

We prepared ZnO@P(CBMA-co-DMAEMA) NPs with Zn(MAA) 2, DMAEMA and CBMA by the sol-gel method [40]. The process of synthesis is shown in Scheme 1a. The relevant parameters of NDDSs with different C(CBMA)/B(DMAEMA) ratios were depicted in Table 1 . It is obvious that they show comparable hydrodynamic diameters $\left(D_{\mathrm{h}}\right)$ with ca. $10 \mathrm{~nm}$ and a relatively small polymer dispersity index (PDI).

Table 1. Structural parameters of different NDDSs.

\begin{tabular}{cccc}
\hline Sample & CBMA/DMAEMA (mg/mg) & $\mathbf{D}_{\mathbf{h}}{ }^{\mathbf{1}}(\mathbf{n m})$ & PDI $^{\mathbf{1}}$ \\
\hline ZnO@PDMAEMA $_{\text {ZnO@PC }}{ }_{200} \mathrm{D}_{600}$ & $0 / 800$ & 10.1 & 0.272 \\
ZnO@PC $_{400} \mathrm{D}_{400}$ & $200 / 600$ & 10.6 & 0.318 \\
ZnO@PC $_{600} \mathrm{D}_{200}$ & $400 / 400$ & 11.7 & 0.386 \\
ZnO@PCBMA & $600 / 200$ & 11.6 & 0.324 \\
\hline
\end{tabular}

${ }^{1} D_{\mathrm{h}}$ and PDI were measured by DLS.

The morphologies of the NDDSs were investigated by TEM. Figure 1 shows the TEM images of $\mathrm{ZnO} @ \mathrm{PC}_{400} \mathrm{D}_{400}$. The $\mathrm{ZnO} @ \mathrm{PC}_{400} \mathrm{D}_{400} \mathrm{NPs}$ are uniform and monodispersed stably in water, exhibiting an approximate particle size of $6 \sim 10 \mathrm{~nm}$. As in seen in Figure 1b, the averaged distance between the $\mathrm{ZnO@} \mathrm{PC}_{400} \mathrm{D}_{400}$ lattices is about $0.25 \mathrm{~nm}$, indicating that adding $\mathrm{PC}_{400} \mathrm{D}_{400}$ does not affect the $\mathrm{ZnO}$ lattice. The crystal phase of $\mathrm{ZnO}$ nanoparticles was further identified by XRD. The XRD patterns of $\mathrm{ZnO@PC}{ }_{400} \mathrm{D}_{400}$ NPs were well matched with the standard JCPDS data card of $\mathrm{ZnO}$ (Figure 2). 

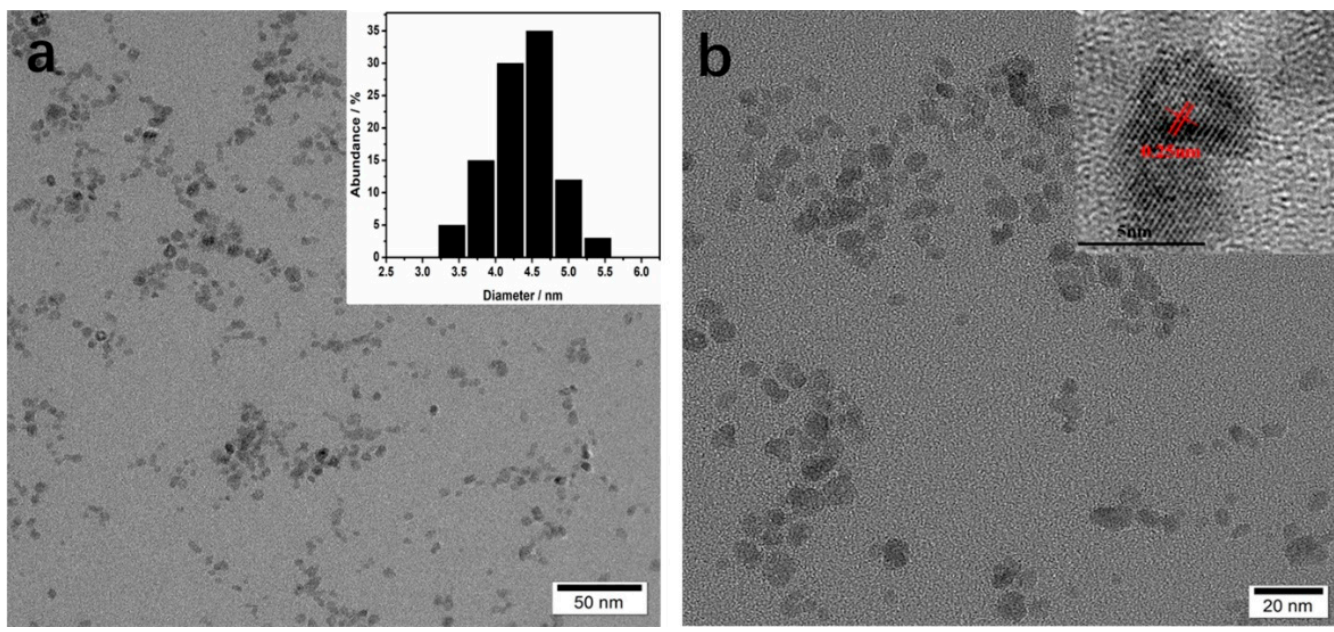

Figure 1. (a) TEM image and (inset) size distribution of $\mathrm{ZnO} @ \mathrm{PC}_{400} \mathrm{D}_{400} \mathrm{NPs}$; (b) TEM image and (inset) HRTEM of $\mathrm{ZnO@PC}{ }_{400} \mathrm{D}_{400} \mathrm{NPs}$.

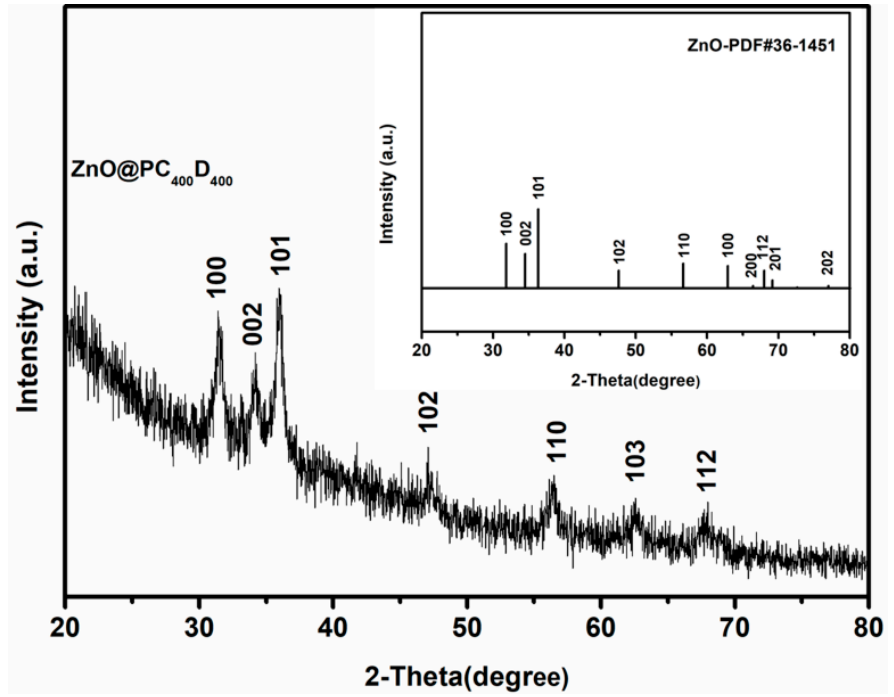

Figure 2. XRD patterns of $\mathrm{ZnO} @ \mathrm{PC}_{400} \mathrm{D}_{400} \mathrm{NPs}$ (the right upper inset was the standard pattern of $\mathrm{ZnO}$ (JCPDS 36-1451)).

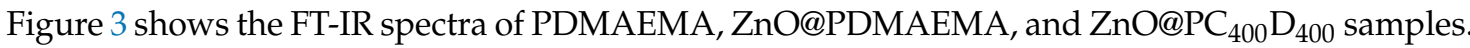
The absorption at $1730 \mathrm{~cm}^{-1}$ (-COOR), $1450 \mathrm{~cm}^{-1}(\mathrm{C}-\mathrm{N})$, and $1150 \mathrm{~cm}^{-1}(\mathrm{C}-\mathrm{O})$ are characteristic absorptions of PDMAEMA, which appeared in PDMAEMA homopolymer, ZnO@PDMAEMA, and $\mathrm{ZnO} @ \mathrm{PC}_{400} \mathrm{D}_{400}$ Compared to PDMAEMA homopolymer, ZnO@PDMAEMA NPs yield two new absorption bands located at $1550 \mathrm{~cm}^{-1}$ and $470 \mathrm{~cm}^{-1}$, which is attributed to unidentate coordination modes of acetate group with $\mathrm{Zn} \mathrm{[41]} \mathrm{and} \mathrm{the} \mathrm{characteristic} \mathrm{absorption} \mathrm{peak} \mathrm{of} \mathrm{Zn}-\mathrm{O}$. The results indicated that PDMAEMA was successfully coated on the surface of ZnO QDs. A new absorption peak at $1650 \mathrm{~cm}^{-1}$ was shown for $\mathrm{ZnO} @ \mathrm{PC}_{400} \mathrm{D}_{400}$, which belonged to the unidentate coordination modes of the acetate group with Na. Another new absorption peak appeared at $3350 \mathrm{~cm}^{-1}$, which indicates that $\mathrm{COO}-$ has been partially converted to $\mathrm{COOH}$. The results indicate that $\mathrm{ZnO} @ \mathrm{P}(\mathrm{CBMA}-\mathrm{co}$-DMAEMA) NPs was successfully prepared. 


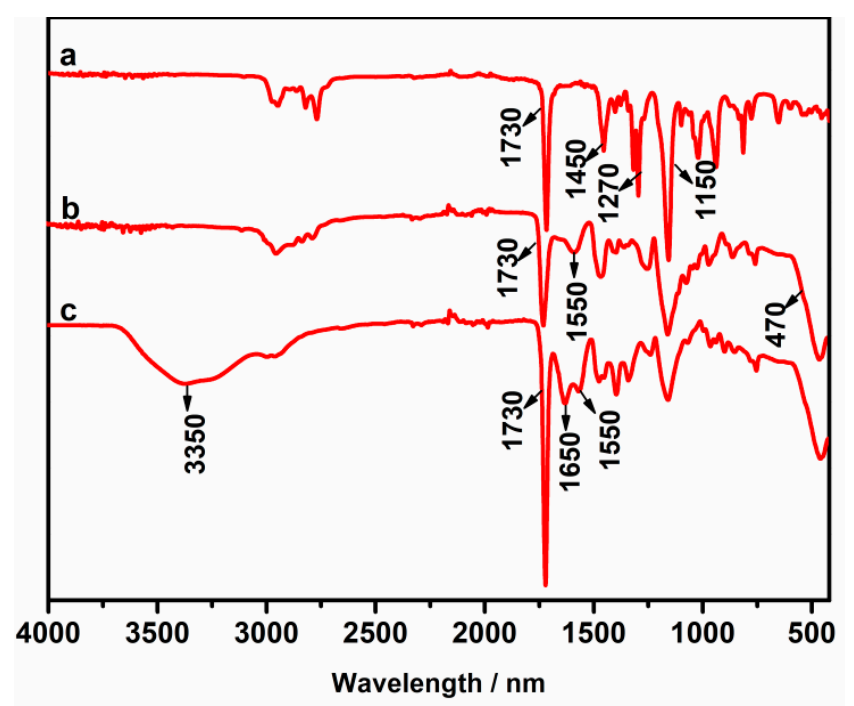

Figure 3. FTIR spectra of (a) PDMAEMA; (b) ZnO@PDMAEMA NPs, and (c) ZnO@PC $400 \mathrm{D}_{400}$ NPs.

We tested the zeta potential of the NDDSs at different $\mathrm{pH}$ (Figure 4a, Table 2). As ZnO QDs can be dissolved under acidic conditions, the measuring $\mathrm{pH}$ was set from 6.5 (ZnO QDs will be dissolved a little, which is not enough to affect the final zeta-potential results) to 8.5. It is noticed for ZnO@PDMAEMA NDDS, the zeta potentials were both positive at $\mathrm{pH}=6.5$ and $\mathrm{pH}=8.5$, and decreased a little from $\mathrm{pH}=6.5$ to $\mathrm{pH}=8.5$. For $\mathrm{ZnO} @ \mathrm{PC}_{200} \mathrm{D}_{600} \mathrm{NDDS}$, the zeta potentials were also positive at both $\mathrm{pH}=7.5$ and $\mathrm{pH}=6.5$. However, as PCBMA content increased, the zeta potential dropped a lot compared to ZnO@PDMAEMA NDDS and decreased rapidly as the pH increased. This is attributed to that when in acidic environment, the number of negatively charged functional groups decrease due to the protonation of carboxyl groups on zinc carboxylate and CBMA, while the number of positively charged groups increase due to the protonation of the unprotonated tertiary amine group. This trend was the same as the CBMA moiety increases. For $\mathrm{ZnO} @ \mathrm{PC}_{400} \mathrm{D}_{400}$ NDDS, the zeta potential became negative $(-0.21)$ at physiological $\mathrm{pH}(7.5)$, while positive (3.14) at the slightly acidic extracellular $\mathrm{pH}$ of tumors (6.5). The negative zeta potential at physiological $\mathrm{pH}$ could help resist protein adsorption and increase the circulation time. This was demonstrated by Figure $3 b$, in which the aggregation behavior of the NDDSs were investigated in $10 \% \mathrm{FBS}$ to evaluate their protein adsorption behavior. The turbidity of ZnO@PDMAEMA dispersed solution reached a high value rapidly, indicating rapid aggregation of ZnO@PDMAEMA in 10\% buffered FBS. In comparison, $\mathrm{ZnO@PC}{ }_{200} \mathrm{D}_{600}$ with decreased positive charges showed less aggregation in $10 \%$ buffered FBS. When the zeta potential became negative $\left(\mathrm{ZnO} @ \mathrm{PC}_{400} \mathrm{D}_{400}, \mathrm{ZnO}_{\mathrm{PPC}} \mathrm{C}_{60} \mathrm{D}_{200}, \mathrm{ZnO} @ \mathrm{PCBMA}\right)$, almost no aggregation in $10 \%$ buffered FBS was observed for 15 days.

For $\mathrm{ZnO} @ \mathrm{PC}_{400} \mathrm{D}_{400} \mathrm{NDDS}$, the negative zeta potential at physiological $\mathrm{pH}$ and positive zeta potential at the slightly acidic $\mathrm{pH}$ not only helps resist protein adsorption, but also contributes to endocytosis. This is because the positively charged $\mathrm{ZnO} @ \mathrm{PC}_{400} \mathrm{D}_{400}$ NDDS in the acidic tumor microenvironment can be better attached to the negatively charged cell membrane, thus increasing endocytosis. In addition, the fast protonation/deprotonation of the $\mathrm{ZnO} @ \mathrm{PC}_{400} \mathrm{D}_{400} \mathrm{NDDS}$ is reversible, which makes the NDDS much safer because the NDDS that do not enter the tumor by endocytosis will restore to their slightly negatively charged state to reduce endocytosis and internalization in healthy tissues. As the CBMA content kept increasing, the NDDSs became all negative at both $\mathrm{pH}=7.5$ and $\mathrm{pH}=6.5$, which was not favorable for endocytosis of tumor cells. As a result, $\mathrm{ZnO@PC} \mathrm{P}_{400} \mathrm{D}_{400}$ NDDS was selected for further research. 

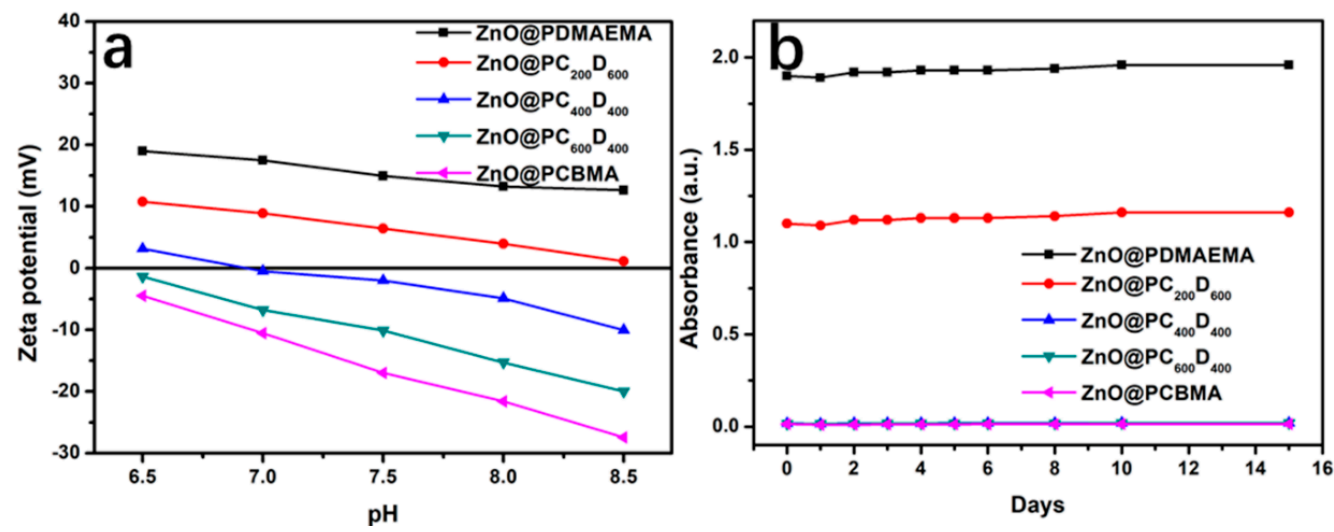

Figure 4. (a) Zeta potential of the ZnO NDDSs at different $\mathrm{pH}$; (b) absorbance at $\lambda=600 \mathrm{~nm}$ showing the turbidity of the NDDSs incubated in $10 \%$ FBS with different times $(0,1,2,3,4,5,6,8,10$, and 15 days).

Table 2. Zetal potential and drug loading contents of the NDDSs.

\begin{tabular}{ccc}
\hline Sample & Zeta-Potential $(\mathbf{m V})(\mathbf{p H}=7.5)$ & Zeta-Potential $(\mathbf{m V})(\mathbf{p H}=\mathbf{6 . 5})$ \\
\hline ZnO@PDMAEMA & 14.94 & 18.99 \\
ZnO@PC ${ }_{200} \mathrm{D}_{600}$ & 6.42 & 10.78 \\
ZnO@PC $_{400} \mathrm{D}_{400}$ & -2.01 & 3.14 \\
ZnO@PC $_{600} \mathrm{D}_{200}$ & -10.12 & -1.38 \\
ZnO@PCBMA & -16.98 & -4.48 \\
\hline
\end{tabular}

The thermogravimetric analysis (TGA) result of $\mathrm{ZnO} @ \mathrm{PC}_{400} \mathrm{D}_{400}$ NDDS is shown in Figure S1. It is seen that the polymers were almost completely decomposed when the temperature reached $400{ }^{\circ} \mathrm{C}$. The weight fraction of $\mathrm{ZnO}$ in $\mathrm{ZnO} @ \mathrm{PC}_{400} \mathrm{D}_{400}$ was about $30 \mathrm{wt} \%$. As is shown in Figure S2, the UV-Vis absorption spectra of the $Z n O @ P C_{400} \mathrm{D}_{400} \mathrm{NPs}$ in aqueous solution stayed unchanged during the 30-days storage, proving that they are very stable in the neutral aqueous solution.

Doxorubicin (DOX) was selected as a model drug for this study. The drug loading content of ZnO@PDMAEMA, and $\mathrm{ZnO} @ \mathrm{PC}_{400} \mathrm{D}_{400}$ decided by UV-vis spectroscopy were $15.5 \%$ and $24.6 \%$ respectively. The relatively high loading content of drug molecules indicated the $\mathrm{ZnO@PC}{ }_{400} \mathrm{D}_{400}$ nanoplatform is a promising candidate as NDDS. The lower drug loading content of ZnO@PDMAEMA resulted from like charges being repelled by the positively charged surface of DOX and ZnO@PDMAEMA. The loading content of $\mathrm{ZnO@PC} 400 \mathrm{D}_{400}$ was much higher than that of ZnO@PDMAEMA, probably because of the zeta potential of $\mathrm{ZnO} @ \mathrm{PC}_{400} \mathrm{D}_{400}$ at physiological $\mathrm{pH}$ reducing to negative, which was more favorable for DOX loading.

Figure $5 \mathrm{a}$ is the UV-vis absorbance spectra of $\mathrm{ZnO} @ \mathrm{PC}_{400} \mathrm{D}_{400}, \mathrm{ZnO}_{\mathrm{P}} \mathrm{PC}_{400} \mathrm{D}_{400}-\mathrm{DOX}$ and free DOX. The characteristic absorbance peak of $\mathrm{ZnO} @ \mathrm{PC}_{400} \mathrm{D}_{400}-\mathrm{DOX}$ at $500 \mathrm{~nm}$ (in accordance with free DOX) indicated that DOX was loaded to $\mathrm{ZnO} @ \mathrm{PC}_{400} \mathrm{D}_{400}$ successfully. There are two

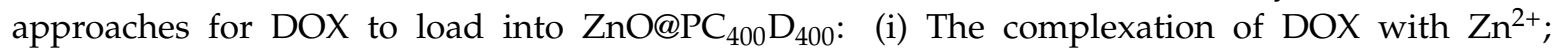
(ii) the adsorption of positively charged DOX to negative $Z n O @ \mathrm{PC}_{400} \mathrm{D}_{400} \mathrm{NDDS}$. The fluorescence spectra of $\mathrm{ZnO} @ \mathrm{PC}_{400} \mathrm{D}_{400}$ were detected after incubation with different $\mathrm{pH}$ solutions (Figure $5 \mathrm{~b}$ ). An emission peak at $550 \mathrm{~nm}$ was observed in physiological $\mathrm{pH}$ when excited at $330 \mathrm{~nm}$, proving that $\mathrm{ZnO}$ QDs with yellow fluorescence were successfully synthesized. The emission peak of $\mathrm{ZnO@PC} \mathrm{P}_{400} \mathrm{D}_{400}$ vanished under mildly acidic conditions, confirming that $\mathrm{ZnO}$ QDs were efficiently decomposed in a weakly acidic environment.

Figure $5 c, d$ show the photographs of aqueous solutions of the NPs under white light and UV light. The aqueous solution of $\mathrm{ZnO} @ \mathrm{PC}_{400} \mathrm{D}_{400}$ is transparent and colorless under white light while it exhibits yellow fluorescence under the excitation $(365 \mathrm{~nm}$ ). The colour of the DOX solutions changes from orange to pink after mixing with $\mathrm{ZnO} @ \mathrm{PC}_{400} \mathrm{D}_{400}$. The solution colour recovered from pink to orange when the $\mathrm{pH}$ of the solutions of $\mathrm{ZnO} @ \mathrm{PC}_{400} \mathrm{D}_{400}-\mathrm{DOX}$ was tuned to below 5.5, suggesting breaking of the coordinate bond between the drug and the metal ion, with the DOX molecules released 
from the NDDS surfaces resultantly. Figure $5 c$,d show the photographs of aqueous solutions of the NPs under white light and UV light. The aqueous solution of $\mathrm{ZnO} @ \mathrm{PC}_{400} \mathrm{D}_{400}$ is transparent and colorless under white light while it exhibits yellow fluorescence under excitation $(365 \mathrm{~nm})$. The colour of the DOX solutions changes from orange to pink after mixing with $\mathrm{ZnO@PC} \mathrm{C}_{400} \mathrm{D}_{400}$. The solution colour recovered from pink to orange when the $\mathrm{pH}$ of the solutions of $\mathrm{ZnO} @ \mathrm{PC}_{400} \mathrm{D}_{400}$ - $\mathrm{DOX}$ was tuned to below 5.5, suggesting breaking of the coordinate bond between the drug and the metal ion with the DOX molecules released from the NDDS surfaces resultantly.
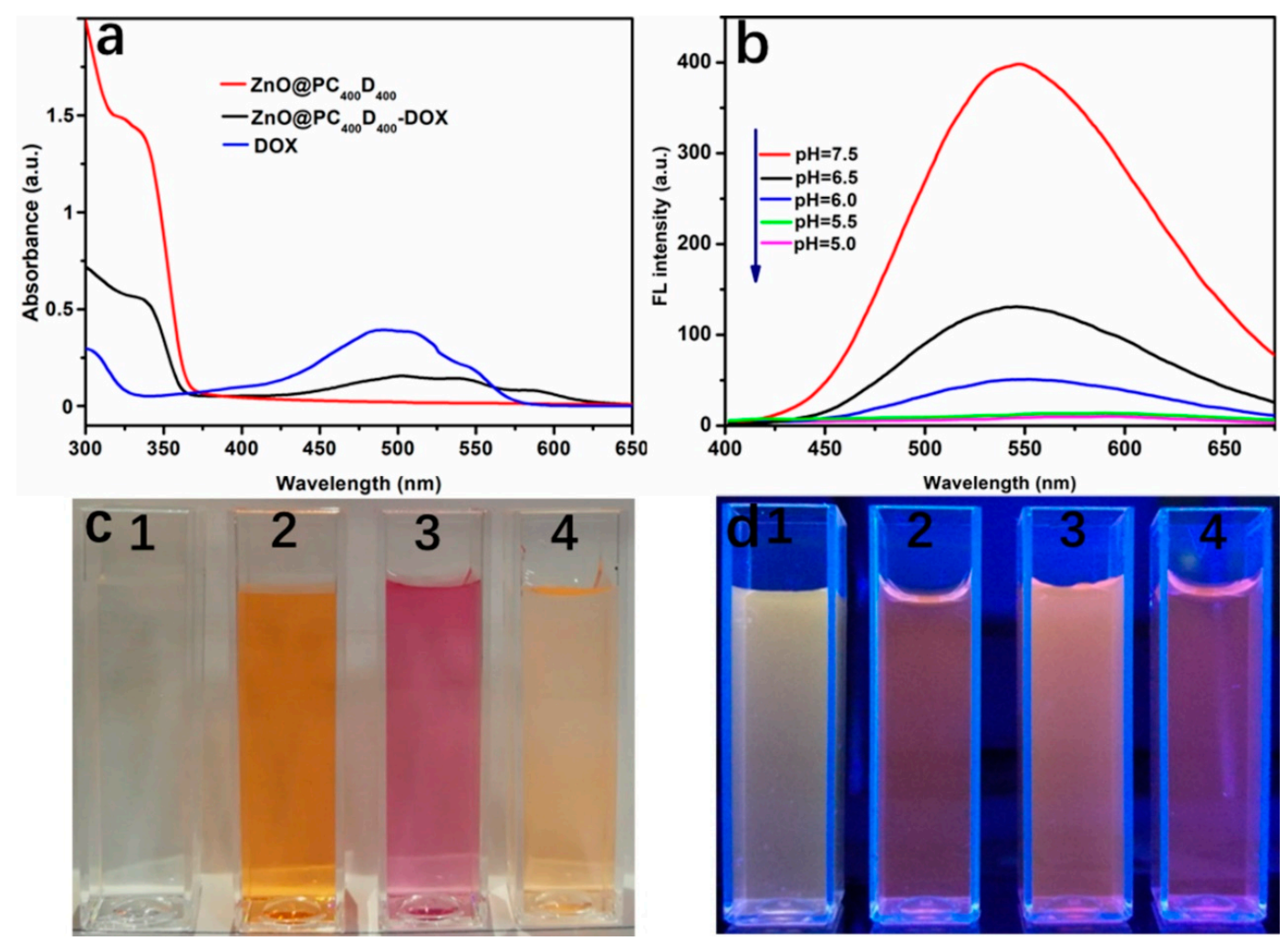

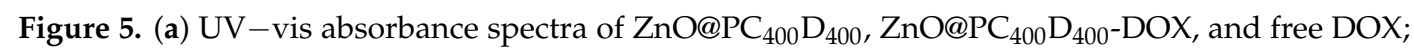
(b) fluorescence spectra of $\mathrm{ZnO} @ \mathrm{PC}_{400} \mathrm{D}_{400}$ incubated at different $\mathrm{pH}$ under an excitation of $330 \mathrm{~nm}$. Photographs of aqueous solutions of (1) ZnO@PC $\mathrm{Z}_{400} \mathrm{D}_{400}$, (2) free DOX, (3) $\mathrm{ZnO} @ \mathrm{PC}_{400} \mathrm{D}_{400}-\mathrm{DOX}$ nanoparticles, and (4) DOX released from $\mathrm{ZnO} @ \mathrm{PC}_{400} \mathrm{D}_{400}$ - $\mathrm{DOX}$ at $\mathrm{pH}=5.0$ under (c) white light and (d) UV light (365 nm).

$\mathrm{pH}$-induced drug release behavior was investigated by fluorescence emission spectroscopy at different $\mathrm{pH}$ ranging from 1 to $5 \mathrm{~h}$. As shown in Figure 6a, the fluorescence intensity of DOX increased a little after $5 \mathrm{~h}$ at $\mathrm{pH}=7.5$. In contrast, the fluorescence intensity of DOX increased rapidly in a short time $(5 \mathrm{~h})$ at $\mathrm{pH}=5.5$ (Figure $6 \mathrm{~b}$ ). The drug release study of $\mathrm{ZnO} @ \mathrm{PC}_{400} \mathrm{D}_{400}-\mathrm{DOX}$ was performed at different $\mathrm{pH}$ over $30 \mathrm{~h}$ (Figure 6c). It is observed that nearly $90 \%$ of DOX was released after $10 \mathrm{~h}$ in $\mathrm{pH}=5.5$ buffer, which simulated the physiological conditions of tumor cells. However, the amount of released DOX was no more than $25.3 \%$ in $\mathrm{pH}=7.5$ buffer, which simulated the physiological conditions of normal cells. The release of DOX was triggered by the decomposition of ZnO QDs and the drug-metal complex in an acidic environment.

CLSM was conducted to investigate the internalization and drug release behaviors in tumor cells (Figure 7). Firstly, HepG2 cells were incubated with $\mathrm{ZnO} @ \mathrm{PC}_{400} \mathrm{D}_{400}$ and $\mathrm{ZnO} @ \mathrm{PC}_{400} \mathrm{D}_{400}$-DOX for $4 \mathrm{~h}$ and then subjected to CLSM observations. The endocytosis of $\mathrm{ZnO}_{\mathrm{PPC}} \mathrm{C}_{400} \mathrm{D}_{400}$ was monitored by the yellow fluorescence of $\mathrm{ZnO}$ QDs. As is seen in Figure 7a, the brightly yellow fluorescence in the cytoplasm clearly demonstrated the successful endocytosis of $\mathrm{ZnO} @ P C_{400} \mathrm{D}_{400}$. The intracellular drug release from $\mathrm{ZnO} @ \mathrm{PC}_{400} \mathrm{D}_{400}-\mathrm{DOX}$ was tracked by the red fluorescence of DOX. In Figure $7 \mathrm{~b}$, 
the red fluorescence in HepG2 cells showed that DOX was successfully released from the NPs to the cells, which demonstrated that $\mathrm{ZnO} @ \mathrm{PC}_{400} \mathrm{D}_{400} \mathrm{NPs}$ were decomposed in the intracellular acidic environment and promoted the drug release.
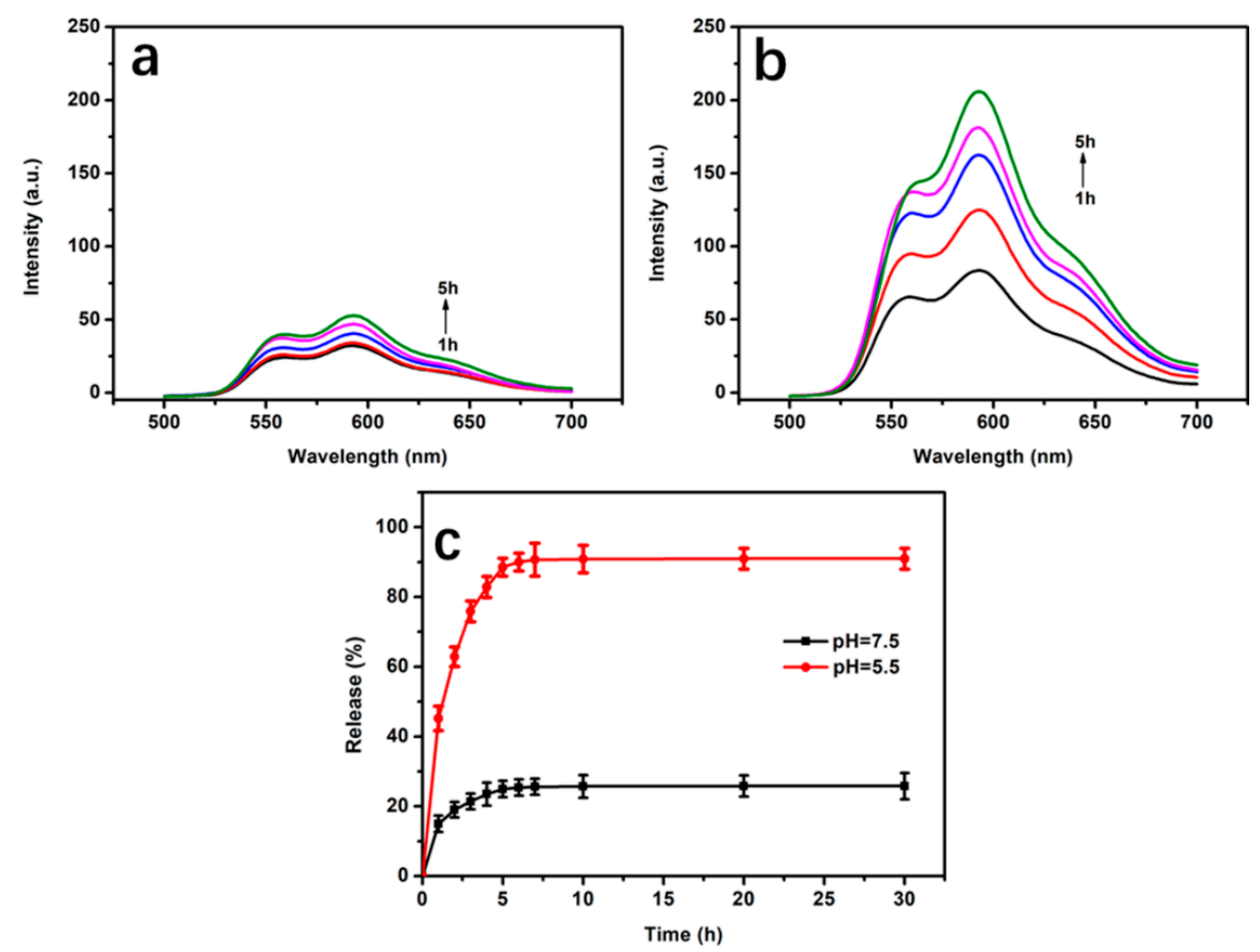

Figure 6. Time-dependent fluorescence spectra of drug release after incubating $\mathrm{ZnO} @ \mathrm{PC}_{400} \mathrm{D}_{400}-\mathrm{DOX}$ at $(\mathbf{a}) \mathrm{pH}=7.5$ and $(\mathbf{b}) \mathrm{pH}=5.5$ at different times $(1-5 \mathrm{~h})$; (c) the drug release profile of the $\mathrm{ZnO} @ \mathrm{PC}_{400} \mathrm{D}_{400}$-DOX on different $\mathrm{pH}$ environments.

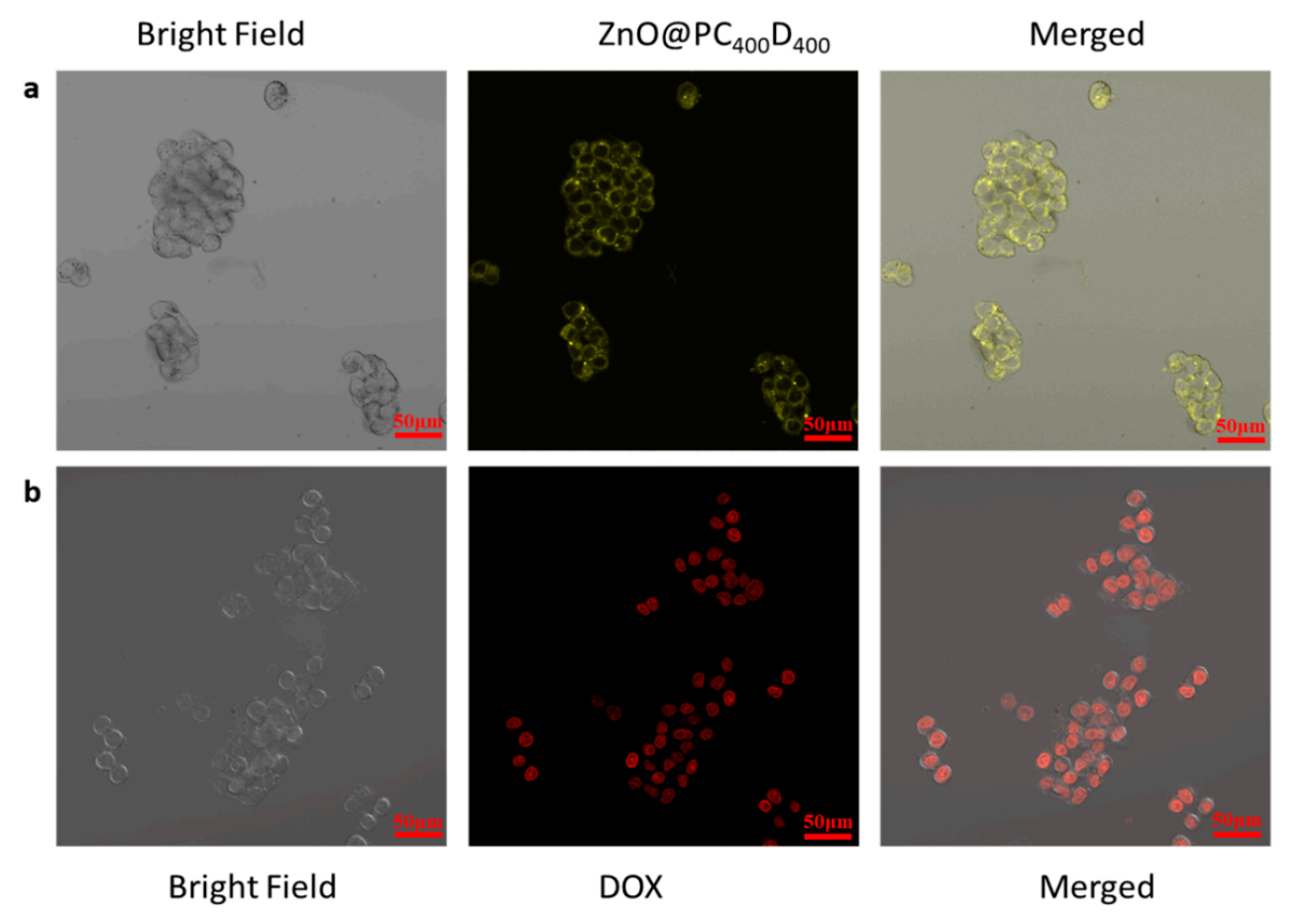

Figure 7. CLSM images in a culture of HepG2 cells of incubation with (a) $\mathrm{ZnO@PC} 400 \mathrm{D}_{400}$ after $4 \mathrm{~h}$

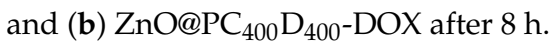


The concentration-dependent cytotoxicity was evaluated with HepG2 cells. As is shown in Figure $8 \mathrm{a}, \mathrm{ZnO}$ QDs and zinc ions $\left(\mathrm{ZnCl}_{2}\right)$ both exhibited significant cytotoxicity, with zinc ions surpassing $20 \mu \mathrm{g} \mathrm{mL}^{-1}$, proving that $\mathrm{ZnO}$ QDs possessed comparable cytotoxicity effects after decomposition into free $\mathrm{Zn}^{2+}$. When the concentration of zinc ions become less than $10 \mu \mathrm{g} \mathrm{mL}{ }^{-1}, \mathrm{ZnO}$ QDs can maintain more than $80 \%$ of cell viability. This is very important for zinc ions that are enriched in acidic cancer cells with cytotoxicity, while not to healthy cells. We also tested the cytotoxicity of the ZnO@PDMAEMA and $\mathrm{ZnO@PC}{ }_{400} \mathrm{D}_{400}$. The results showed that at a concentration of $40 \mu \mathrm{g} \mathrm{mL} \mathrm{L}^{-1}$, more than $90 \%$ of HepG2 cells were viable for $\mathrm{ZnO@PC}{ }_{400} \mathrm{D}_{400}$. This is due to that the negatively charged $\mathrm{ZnO@PC}{ }_{400} \mathrm{D}_{400}$ encapsulating the $\mathrm{ZnO}$ QDs, which shields the inside QDs and reduces the cytotoxicity. However, when the concentration increased to $40 \mu \mathrm{g} \mathrm{mL}^{-1}$, only $45 \%$ of the cells in medium with addition of ZnO@PDMAEMA survived. This is because PDMAEMA is positively charged with cytotoxicity. As shown in Figure 8b, for the $\mathrm{ZnO} @ \mathrm{PC}_{400} \mathrm{D}_{400}$-DOX group, cell viability decreased to approximately $20.6 \%$ at $5 \mu \mathrm{g} \mathrm{mL}^{-1} \mathrm{DOX}$, which is even more cytotoxic than free DOX (with a cell viability of $26.7 \%$ ), clearly proving DOX released in the acidic environment of tumors and the synergistic therapy of $\mathrm{Zn}^{2+}$.

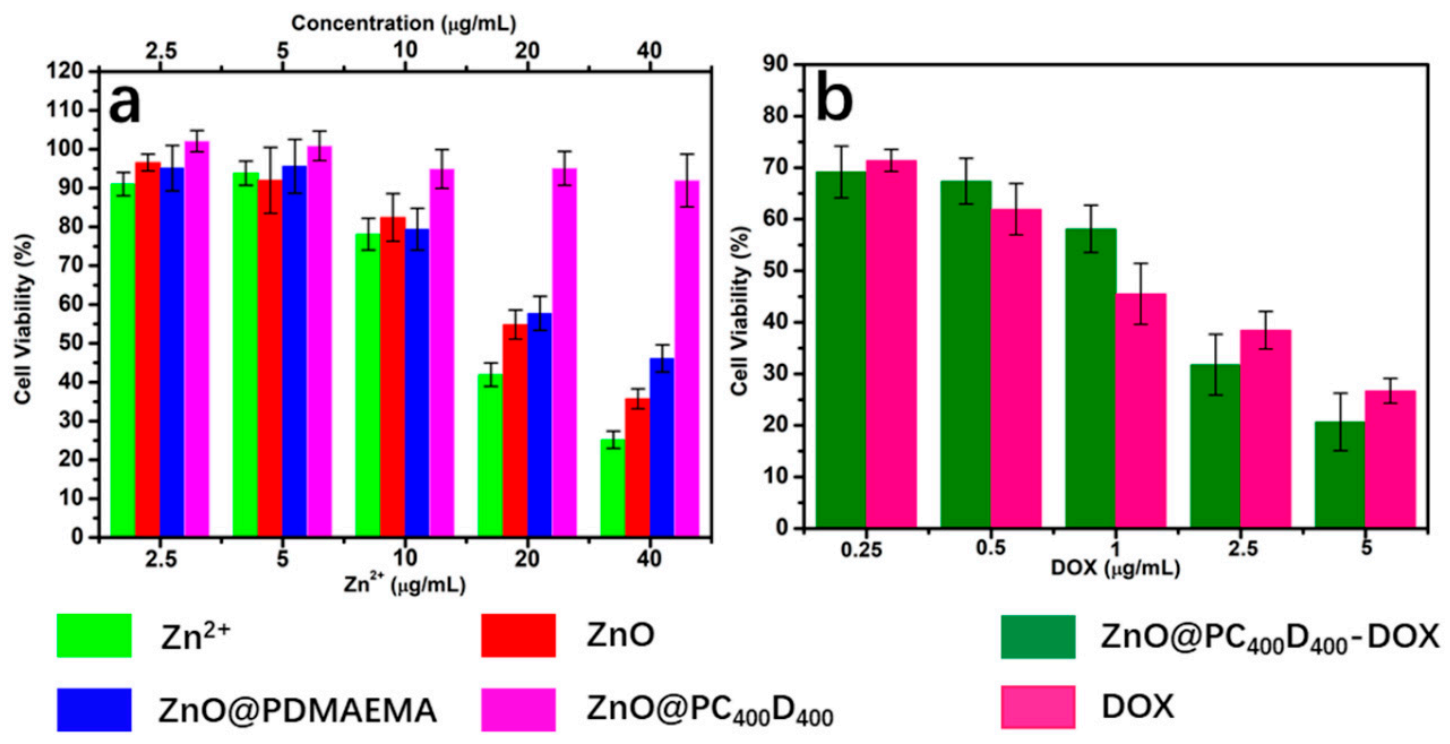

Figure 8. Cytotoxicity assay of HepG2 cells after $24 \mathrm{~h}$ of incubation with (a) ZnO QDs and comparable concentrations of Zn2+ ions, ZnO@PDMAEMA, and $\mathrm{ZnO} @ \mathrm{PC}_{400} \mathrm{D}_{400}$; (b) $\mathrm{ZnO@PC} 400 \mathrm{D}_{400}-\mathrm{DOX}$ and free DOX.

\section{Conclusions}

In conclusion, we have created ZnO@P(CBMA-co-DMAEMA) NDDS with ZnO quantum dot as the fluorescence core and zwitterionic P(CBMA-co-DMAEMA) as the shell. The ZnO@P(CBMA-co-DMAEMA) NDDS possess excellent fluorescence properties for cell imaging and drug delivery. The surface protonation/deprotonation controlled charge switch of $\mathrm{P}(\mathrm{CBMA}-c o$-DMAEMA) help increase blood circulation time and promote endocytosis. DOX were successfully loaded to ZnO@P(CBMA-co-DMAEMA) with a relatively large drug loading content $(24.6 \%)$. The NDDS remained stable at physiological $\mathrm{pH}$ while it decomposed to release DOX under acidic intracellular conditions, resulting in synergistic treatment of cancer due to incorporation of the antitumor effect of $\mathrm{Zn}^{2+}$ and DOX. These advantages make ZnO@P(CBMA-co-DMAEMA) NDDSs a desirable unique drug delivery system for cancer treatment.

Supplementary Materials: The following are available online at http:/ / www.mdpi.com/2073-4360/10/11/1272/ s1, Figure S1: Thermogravimetric Analysis (TGA) of $Z n O @ \mathrm{PC}_{400} \mathrm{D}_{400}$, Figure S2: UV-Vis absorption spectra of $\mathrm{ZnO@PC} 400 \mathrm{D}_{400}$ at different storage time at room temperature. 
Author Contributions: Y.W., L.H and B.Y. contributed to this work equally. Conceptualization, Y.W., L.H. and H.C; methodology, L.H., Y.W. and B.Y; software, L.H.; validation, Y.W. and L.H.; formal analysis, L.H. and Y.W.; investigation, L.H. and Y.C.; resources, Y.W. and H.C; data curation, L.H.; writing-original draft preparation, L.H.; writing - review and editing, Y.W.; visualization, Y.W.; supervision, H.C. and Y.S.; project administration, H.C and B.Y.; funding acquisition, H.C., B.Y. and Y.W.

Funding: This work was supported by the National Natural Science Foundation of China (21874078, 21574072, 21675091), the Taishan Young Scholar Program of Shandong Province (tsqn20161027), the Major Science and Technology Innovation Project of Shandong Province (2018CXGC1407), the Key Research and Development Project of Shandong Province (2016GGX102028, 2016GGX102039, 2017GGX20111), the Project of Shandong Province Higher Educational Science and Technology Program (J15LC20), the Natural Science Foundation of Shandong Province (ZR2017BEM012), the People's Livelihood Science and Technology Project of Qingdao (166257nsh, 173378nsh), the Innovation Leader Project of Qingdao (168325zhc), and the First Class Discipline Project of Shandong Province.

Acknowledgments: The authors thank the Institute of Materials Science and Engineering, Qingdao University for financial and human resources support.

Conflicts of Interest: The authors declare no conflict of interest.

\section{References}

1. Chang, R.; Tsai, W.B. Fabrication of Photothermo-Responsive Drug-Loaded Nanogel for Synergetic Cancer Therapy. Polymers 2018, 10, 1098. [CrossRef]

2. Agrawal, G.; Agrawal, R. Stimuli-Responsive Microgels and Microgel-Based Systems: Advances in the Exploitation of Microgel Colloidal Properties and Their Interfacial Activity. Polymers 2018, 10, 418. [CrossRef]

3. Blanco, E.; Shen, H.; Ferrari, M. Principles of nanoparticle design for overcoming biological barriers to drug delivery. Nat. Biotechnol. 2015, 33, 941-951. [CrossRef] [PubMed]

4. Seidi, K.; Neubauer, H.A.; Moriggl, R.; Jahanban-Esfahlan, R.; Javaheri, T. Tumor target amplification: implications for nano drug delivery systems. J. Control. Release 2018, 275, 142-161. [CrossRef] [PubMed]

5. Ngo, B.K.D.; Grunlan, M.A. Protein Resistant Polymeric Biomaterials. ACS Macro Lett. 2017, 6, $992-1000$. [CrossRef]

6. Liu, Z.; Robinson, J.T.; Sun, X.; Dai, H. PEGylated Nano-Graphene Oxide for Delivery of Water Insoluble Cancer Drugs. J. Am. Chem. Soc. 2008, 130, 10876-10877. [CrossRef] [PubMed]

7. Pelaz, B.; Del, P.P.; Maffre, P.; Hartmann, R.; Gallego, M.; Rivera-Fernández, S.; Jm, D.L.F.; Nienhaus, G.U.; Parak, W.J. Surface Functionalization of Nanoparticles with Polyethylene Glycol: Effects on Protein Adsorption and Cellular Uptake. ACS Nano 2015, 9, 6996-7008. [CrossRef] [PubMed]

8. Shao, Q.; Jiang, S. Molecular Understanding and Design of Zwitterionic Materials. Adv. Mater. 2015, 27, 15-26. [CrossRef] [PubMed]

9. Chen, Y.; Xiong, Z.; Zhang, L.; Zhao, J.; Zhang, Q.; Peng, L.; Zhang, W.; Ye, M.; Zou, H. Facile synthesis of zwitterionic polymer-coated core-shell magnetic nanoparticles for highly specific capture of $\mathrm{N}$-linked glycopeptides. Nanoscale 2015, 7, 3100-3108. [CrossRef] [PubMed]

10. Ou, H.; Cheng, T.; Zhang, Y.; Liu, J.; Ding, Y.; Zhen, J.; Shen, W.; Xu, Y.; Yang, W.; Niu, P. Surface-adaptive zwitterionic nanoparticles for prolonged blood circulation time and enhanced cellular uptake in tumor cells. Acta Biomater. 2017, 65, 339-348. [CrossRef] [PubMed]

11. Zhou, W.; Shao, J.; Jin, Q.; Wei, Q.; Tang, J.; Ji, J. Zwitterionic phosphorylcholine as a better ligand for gold nanorods cell uptake and selective photothermal ablation of cancer cells. Chem. Commun. 2010, 46, 1479-1481. [CrossRef] [PubMed]

12. Knop, K.; Hoogenboom, R.; Fischer, D.; Schubert, U.S. Poly(ethylene glycol) in drug delivery: Pros and cons as well as potential alternatives. Angew. Chem. Int. Ed. 2011, 42, 6288-6308. [CrossRef] [PubMed]

13. Yuan, Y.Y.; Mao, C.Q.; Du, X.J.; Du, J.Z.; Wang, F.; Wang, J. Surface Charge Switchable Nanoparticles Based on Zwitterionic Polymer for Enhanced Drug Delivery to Tumor. Adv. Mater. 2012, 24, 5476-5480. [CrossRef] [PubMed]

14. Chen, H.; Zhang, M.; Li, B.; Chen, D.; Dong, X.; Wang, Y.; Gu, Y. Versatile antimicrobial peptide-based $\mathrm{ZnO}$ quantum dots for in vivo bacteria diagnosis and treatment with high specificity. Biomaterials 2015, 53, 532-544. [CrossRef] [PubMed] 
15. Zheng, K.; Lu, M.; Rutkowski, B.; Dai, X.Y.; Yang, Y.; Taccardi, N.; Stachewicz, U.; Czyrska-Filemonowicz, A.; Hüser, N.; Boccaccini, A.R. ZnO quantum dots modified bioactive glass nanoparticles with pH-sensitive release of $\mathrm{Zn}$ ions, fluorescence, antibacterial and osteogenic properties. J. Mater. Chem. B 2016, 4, 7936-7949. [CrossRef]

16. Wu, S.; Huang, X.; Du, X. pH- and Redox-Triggered Synergistic Controlled Release of ZnO-Gated Hollow Mesoporous Silica Drug Delivery System. J. Mater. Chem. B 2015, 3, 1426-1432. [CrossRef]

17. Zhang, J.; Wu, D.; Li, M.F.; Feng, J. Multifunctional Mesoporous Silica Nanoparticles Based on Charge-Reversal Plug-Gate Nanovalves and Acid-Decomposable ZnO Quantum Dots for Intracellular Drug Delivery. ACS Appl. Mater. Interfaces 2015, 7, 26666-26673. [CrossRef] [PubMed]

18. Othman, B.A.; Greenwood, C.; Abuelela, A.F.; Bharath, A.A.; Chen, S.; Theodorou, I.; Douglas, T.; Uchida, M.; Ryan, M.; Merzaban, J.S. Correlative Light-Electron Microscopy Shows RGD—Targeted ZnO Nanoparticles Dissolve in the Intracellular Environment of Triple Negative Breast Cancer Cells and Cause Apoptosis with Intratumor Heterogeneity. Adv. Healthc. Mater. 2016, 5, 1310-1325. [CrossRef] [PubMed]

19. Depan, D.; Misra, R.D. Structural and physicochemical aspects of silica encapsulated ZnO quantum dots with high quantum yield and their natural uptake in HeLa cells. J. Biomed. Mater. Res. A 2014, 102, 2934-2941. [CrossRef] [PubMed]

20. Sandmann, A.; Kompch, A.; Mackert, V.; Liebscher, C.H.; Winterer, M. Interaction of L-cysteine with ZnO: Structure, surface chemistry and optical properties. Langmuir 2015, 31, 5701-5711. [CrossRef] [PubMed]

21. Mirzaei, H.; Darroudi, M. Zinc oxide nanoparticles: Biological synthesis and biomedical applications. Ceram. Int. 2017, 43, 907-914. [CrossRef]

22. Matsuyama, K.; Maeda, Y.K.; Matsuda, T.; Okuyama, T.; Muto, H. Formation of poly(methyl methacrylate)- $\mathrm{ZnO}$ nanoparticle quantum dot composites by dispersion polymerization in supercritical CO 2. J. Supercrit. Fluids 2015, 103, 83-89. [CrossRef]

23. Han, X.; Huang, S.; Wang, Y.; Shi, D. Design and development of anisotropic inorganic/polystyrene nanocomposites by surface modification of zinc oxide nanoparticles. Mater. Sci. Eng. C 2016, 64, 87-92. [CrossRef] [PubMed]

24. Yang, W.; Wang, L.; Lu, X.; Zhang, Q. Enhancing luminescence of ZnO quantum dots by PEG and oleic acid via a sol-gel method. J. Mater. Sci. Mater. Electron. 2015, 26, 1113-1118. [CrossRef]

25. Muhammad, F.; Guo, M.; Guo, Y.; Qi, W.; Qu, F.; Sun, F.; Zhao, H.; Zhu, G. Acid degradable ZnO quantum dots as a platform for targeted delivery of an anticancer drug. J. Mater. Chem. 2011, 21, 13406-13412. [CrossRef]

26. Cai, X.; Luo, Y.; Zhang, W.; Du, D.; Lin, Y. pH-Sensitive ZnO Quantum Dots-Doxorubicin Nanoparticles for Lung Cancer Targeted Drug Delivery. ACS Appl. Mater. Interfaces 2016, 8, 22442-22450. [CrossRef] [PubMed]

27. Zhang, P.; Liu, W. ZnO QD@PMAA-co-PDMAEMA nonviral vector for plasmid DNA delivery and bioimaging. Biomaterials 2010, 31, 3087-3094. [CrossRef] [PubMed]

28. Shouju, W.; Zhaogang, T.; Peng, H.; Dingbin, L.; Ying, L.; Ying, T.; Jing, S.; Yanjun, L.; Huangxian, J.; Xiaoyuan, C. Photothermal Therapy: Reversibly Extracellular $\mathrm{pH}$ Controlled Cellular Uptake and Photothermal Therapy by PEGylated Mixed-Charge Gold Nanostars. Small 2015, 11, 1801-1810.

29. Li, H.J.; Du, J.Z.; Liu, J.; Du, X.J.; Shen, S.; Zhu, Y.H.; Wang, X.; Ye, X.; Nie, S.; Wang, J. Smart Superstructures with Ultrahigh $\mathrm{pH}$-Sensitivity for Targeting Acidic Tumor Microenvironment: Instantaneous Size Switching and Improved Tumor Penetration. ACS Nano 2016, 10, 6753-6761. [CrossRef] [PubMed]

30. Stubbs, M.; Mcsheehy, P.M.J.; Griffiths, J.R.; Bashford, C.L. Causes and consequences of tumour acidity and implications for treatment. Mol. Med. Today 2000, 6, 15-19. [CrossRef]

31. Onyango, J.O.; Chung, M.S.; Eng, C.H.; Klees, L.M.; Langenbacher, R.; Yao, L.; An, M. Noncanonical Amino Acids to Improve the $\mathrm{pH}$ Response of pHLIP Insertion at Tumor Acidity. Angew. Chem. Int. Ed. 2015, 54, 3658-3663. [CrossRef] [PubMed]

32. Wan, P.; Bernards, M.T.; Deng, B. Modification of polysulfone (PSF) hollow fiber membrane (HFM) with zwitterionic or charged polymers. Ind. Eng. Chem. Res. 2017, 56, 7576-7584. [CrossRef]

33. Li, B.; Yuan, Z.; Peng, Z.; Sinclair, A.; Jain, P.; Kan, W.; Tsao, C.; Xie, J.; Hung, H.C.; Lin, X. Zwitterionic Nanocages Overcome the Efficacy Loss of Biologic Drugs. Adv. Mater. 2018, 30, 1705728. [CrossRef] [PubMed] 
34. Zhang, P.; Sun, F.; Tsao, C.; Liu, S.; Jain, P.; Sinclair, A.; Hung, H.C.; Bai, T.; Wu, K.; Jiang, S. Zwitterionic gel encapsulation promotes protein stability, enhances pharmacokinetics, and reduces immunogenicity. Proc. Natl. Acad. Sci. USA 2015, 112, 12046-12051. [CrossRef] [PubMed]

35. Liu, P.; Xu, G.; Pranantyo, D.; Xu, L.Q.; Neoh, K.G.; Kang, E.T. pH-Sensitive Zwitterionic Polymer as an Antimicrobial Agent with Effective Bacterial Targeting. ACS Biomater. Sci. Eng. 2017, 4, 40-46. [CrossRef]

36. Chen, K.; Hu, F.; Gu, H.; Xu, H. Tuning of surface protein adsorption by spherical mixed charged silica brushes (MCB) with zwitterionic carboxybetaine component. J. Mater. Chem. B 2017, 5, 435-443. [CrossRef]

37. Vaisocherová, H.; Ševců, V.; Adam, P.; Špačková, B.; Hegnerová, K.; de los Santos Pereira, A.; Rodriguez-Emmenegger, C.; Riedel, T.; Houska, M.; Brynda, E.; et al. Functionalized ultra-low fouling carboxy- and hydroxy-functional surface platforms: Functionalization capacity, biorecognition capability and resistance to fouling from undiluted biological media. Biosens. Bioelectron. 2014, 51, 150-157. [CrossRef] [PubMed]

38. Zhang, Z.; Wan, J.; Sun, L.; Li, Y.; Guo, J.; Wang, C. Zinc finger-inspired nanohydrogels with glutathione/pH triggered degradation based on coordination substitution for highly efficient delivery of anti-cancer drugs. J. Control. Release 2016, 225, 96-108. [CrossRef] [PubMed]

39. Ye, D.X.; Ma, Y.Y.; Zhao, W.; Cao, H.M.; Kong, J.L.; Xiong, H.M.; Möhwald, H. ZnO-Based Nanoplatforms for Labeling and Treatment of Mouse Tumors without Detectable Toxic Side Effects. ACS Nano 2016, 10, 4294-4300. [CrossRef] [PubMed]

40. Hasnidawani, J.N.; Azlina, H.N.; Norita, H.; Bonnia, N.N.; Ratim, S.; Ali, E.S. Synthesis of ZnO Nanostructures Using Sol-Gel Method. Procedia Chem. 2016, 19, 211-216. [CrossRef]

41. Xiong, H.M.; Zhao, X.; Chen, J.S. Inorganic Nanocomposites PEO-ZnO and PEO-ZnO-LiClO 4 Films. J. Phy. Chem. B 2001, 105, 10169-10174. [CrossRef]

(C) 2018 by the authors. Licensee MDPI, Basel, Switzerland. This article is an open access article distributed under the terms and conditions of the Creative Commons Attribution (CC BY) license (http://creativecommons.org/licenses/by/4.0/). 